\title{
Government public relations dalam pengembangan pariwisata masa pandemi COVID-19 di Geopark Ciletuh
}

\begin{abstract}
Ade Kadarisman
Universitas Padjadjaran, Bandung, Indonesia

ABSTRAK

Pada tahun 2018 Geopark Ciletuh telah mendapatkan predikat Global Geopark Network oleh UNESCO. Dengan kondisi alam yang sangat menarik membuat Geopark Ciletuh menjadi salah satu tujuan wisata favorit bagi wisatawan Nasional maupun Internasional, serta menjadi salah satu wisata ungguluan Jawa Barat. Pandemi COVID-19 menjadi penyebab ketidakstabilan sektor pariwisata karena semua kegiatan pariwisata terhenti mengikuti kebijakan Pembatasan Sosial Berskala Besar oleh Pemerintah dengan tujuan untuk menekan penyebaran pandemi. Peran government public relations yaitu mengamati perubahan atau dinamika dalam masyarakat, memberikan informasi dengan baik kepada masyarakat, dapat menjembatani antara masyarakat dengan pemerintah, dan dapat menyelaraskan antara permasalahan dalam masyarakat dengan informasi kehumasan dengan baik. Penelitian ini bertujuan untuk mengetahui peran government public relations dalam pengembangan pariwisata masa pandemi COVID-19 di Geopark Ciletuh. Metode penelitian yang digunakan yaitu deskriptif pendekatan kualitatif dengan studi lapangan. Hasil penelitian menunjukan peran government public relations dalam menyampaikan kebijakan-kebijakan untuk menanggulangi dan melakukan pengembangan pariwisata Geopark Ciletuh telah dilakukan yaitu dengan memberikan informasi mengenai protokol kesehatan dalam kegiatan pariwisata di Geopark Ciletuh meskipun informasi yang diberikan belum merata diketahui oleh masyarakat, khususnya masyarakat di sekitar Geopark Ciletuh. Selain itu, pemerintah telah memetakan hubungan sosio-ekologi di kawasan Geopark Ciletuh dan kebijakan pembukaan tempat wisata di era new normal. Bagi pemerintah daerah yang membawahi Geopark Ciletuh, informasi mengenai protokol kesehatan di wilayah Ciletuh perlu disosialisasikan kepada seluruh stakeholder. Penyebaran informasinya bisa dibagi kepada 8 stakeholder kecamatan dan komunitas-komunitas setempat. Sehingga, informasi mengenai protokol kesehatan di wilayah wisata Ciletuh bisa diterapkan secara maksimal, sebagai upaya mencegah persebaran virus COVID-19.
\end{abstract}

Kata-kata Kunci: Government public relations; kebijakan pemerintah; Geopark Ciletuh; pariwisata; pandemi COVID-19

\section{Government public relations in tourism development during COVID-19 pandemic at Geopark Ciletuh}

\section{ABSTRACT}

In 2018 the Ciletuh Geopark was awarded the Global Geopark Network by UNESCO. Ciletuh Geopark is one of the favorite tourist destinations for national and international tourists and one of West Java tourism flagships with beautiful natural conditions. The COVID-19 pandemic is the cause of instability in the tourism sector as all tourism activities have stopped following the Government's Large-Scale Social Restrictions policy to suppress the pandemic's spread. Government public relations' role is to observe changes or dynamics in society, provide the right amount of information to the community, bridge the community and government, and harmonize problems in society with public relations information properly. This study aims to determine the role of government public relations in tourism development during the COVID-19 pandemic at Ciletuh Geopark. The method used in this research is a descriptive qualitative approach with field studies. The results show that the role of government public relations in delivering policies to overcome and develop Ciletuh Geopark tourism has been carried out, namely by providing information about health protocols in tourism activities at Ciletuh Geopark even though the information provided is not distributed well towards the community, especially the people around the Geopark. Ciletuh. The government has also mapped the socio-ecological relationship in the Ciletuh Geopark area and the policy of opening tourist attractions in the new-normal era. In the Ciletuh Geopark, the local government would share information about health protocols in the Ciletuh area for all stakeholders. The information dissemination was shared among eight sub-district stakeholders and local communities. So, information about health protocols in the tourist area of Ciletuh can be optimally implemented to prevent the spread of the COVID-19 virus.

Keywords: Government public relations; government policy; Ciletuh Geopark; tourism; the COVID-19 pandemic

Korespondensi: Ade Kadarisman, S.Sos., MT., M.Sc., Universitas Padjadjaran, Jl. Raya Bandung Sumedang KM 21, Jatinangor 45363, Email: ade.kadarisman@unpad.ac.id. 


\section{PENDAHULUAN}

Indonesia merupakan negara kepulauan yang kaya akan sumber daya alam, budaya, maupun sumber daya manusianya. Kekayaan Indonesia yang melimpah dan menarik membuat wisatawan terpikat untuk mengunjungi daerahdaerah wisata di Indonesia. Pada umumnya masyarakat melakukan kegiatan pariwisata sebagai obat untuk rasa lelah dan penat ataupun untuk menikmati kekayaan alam Indonesia bersama orang terdekat. Kekayaan destinasi wisata yang dimiliki oleh Indonesia memang menarik untuk dikunjungi bagi wisatawan lokal maupun internasional.

Kegiatan parwisata pada umumnya dilakukan dengan melakukan sebuah perjalanan ke suatu tempat dengan tujuan untuk bersenangsenang. Dalam Undang-Undang No. 10 tahun 2009 disebutkan bahwa pariwisata adalah segala macam kegiatan wisata dan didukung oleh fasilitas yang telah disediakan oleh masyarakat, pengusaha, pemerintah pusat, dan pemerintah daerah. Sementara wisata merupakan kegiatan perjalanan yang dilakukan oleh satu orang atau lebih dengan mengunjungi tempat tertentu dengan tujuan untuk rekreasi, pengembangan pribadi, atau mempelajari keunikan daya tarik wisata yang dikunjungi dalam jangka waktu sementara. Dalam Soebagyo menjelaskan, pariwisata adalah kegiatan perjanalan yang dilakukan sementara oleh seorang individu atau kelompok yang bertujuan untuk mendapatkan kebahagiaan, keseimbangan, maupun keserasian dengan lingkungan yang dikunjunginya (Spilane, 1987).

MenurutPrimadany, mengatakan pariwisata harus memenuhi empat kriteria di bawah ini, yaitu: 1) perjalanan dilakukan dari suatu tempat ke tempat lain, perjalanan dilakukan di luar tempat kediaman di mana orang itu biasanya tinggal; 2) tujuan perjalanan dilakukan sematamata untuk bersenang-senang, tanpa mencari nafkah di negara, kota atau Daerah Tujuan Wisata (DTW) yang dikunjungi; 3) uang yang dibelanjakan wisatawan tersebut dibawa dari negara asalnya, di mana dia bisa tinggal atau berdiam, dan bukan diperoleh karena hasil usaha selama dalam perjalanan wisata yang dilakukan; dan 4) perjalanan dilakukan minimal 24 jam atau lebih (Primadany, 2013).

Herdiana menyebutkan terdapat dua elemen utama dari pariwisata, yaitu wisatawan dan daya tarik wisata (Herdiana, 2020). UndangUndang No.10 tahun 2009 menyebutkan, wisatawan adalah individu atau kelompok yang melakukan perjalanan wisata, sementara daya tarik wisata merupakan segala potensi yang dimiliki oleh suatu daerah yang dapat menarik kedatangan wisatawan, baik potensi yang berupa alam, sosial-budaya, maupun keunikan, serta keindahan tempat tersebut. 
Dalam undang-undang tersebut juga disebutkan bahwa dalam pembangunan kepariwisataan perlu memperhatikan keanekaragaman, keunikan, dan kekhasan budaya dan alam, serta kebutuhan manusia untuk berpariwisata. Pembangunan kepariwisatan meliputi industri pariwisata, destinasi pariwisata, pemasaran, dan kelembagaan kepariwisataan. Soebagyo mengatakan sektor pariwisata merupakan sektor industri terbesar dalam pembiayaan dan akan menjadi pendorong utama dalam sektor perekonomian Indonesia (Soebagyo, 2012).

Pariwisata menjadi sebuah kegiatan yang dicari oleh masyarakat, baik yang muda maupun yang sudah tua, baik penduduk lokal maupun mancanegara. Utomo (25 November 2019) mengatakan, dari situs CNTraveler, berdasarkan Survei Readers' Choice, Indonesia berada di peringkat pertama dunia sebagai negara wisata terfavorit, mengalahkan Thailand, Turki, Jepang, dan 16 negara lainnya. Banyaknya pilihan wisata di Indonesia dapat menjadi daya tarik tersendiri bagi wisatawan lokal maupun luar negeri sehingga dapat meningkatkan devisa negara, membuka banyak lapangan pekerjaan, serta dapat ikut serta dalam memperkenalkan beragam kebudayaan Indonesia ke mata dunia.

Sektor pariwisata merupakan salah satu sektor yang membantu dalam meningkatkan perekonomian daerah. Masyarakat setempat dapat menyediakan lapangan pekerjaan bagi masyarakat lainnya, seperti membuka penginapan, membuat kerajinan tangan sebagai buah tangan, membuka tempat makan, ataupun dengan menyediakan kebutuhan yang mungkin dapat membantu wisatawan dalam menikmati kegiatan wisatanya.

Provinsi Jawa Barat, khususnya Kabupaten Sukabumimenjadi salah satu destinasipariwisata yang sering dikunjungi oleh wisatawan lokal maupun wisatawan asing. Kabupaten Sukabumi memiliki Geopark Ciletuh yang memiliki daya tarik tersendiri bagi para wisatawan, baik dalam maupun luar negeri. Geopark Ciletuh merupakan salah satu Geopark di Indonesia yang telah diresmikan menjadi Global Geopark Network (GGN) oleh UNESCO pada April 2018 lalu. UNSECO menyebutkan terdapat enam kriteria suatu wilayah untuk dapat dijadikan GGN, diantaranya harus memiliki batasan wilayah yang cukup luas dengan mencakup ekonomi dan budaya lokal sebagai pengembangan pariwisata, serta kondisi wilayah yang memiliki kepentingan daerah, nasional, dan internasional.

Kriteria GGN yaitu adanya manajemen dan keterlibatan peran masyarakat lokal dalam mengelola Geopark. Kriteria lainnya yaitu adanya pengembangan ekonomi masyarakat lokal, ketersediaan sarana pendukung dalam bidang pendidikan (museum dan riset), perlindungan dan konservasi, serta keterlibatan dalan jaringan geopark dunia (UNESCO, 2014). 
Geopark Ciletuh memang memiliki banyak destinasi untuk dikunjung, seperti air terjun (Curug Cimarinjung, Curug Sodong, Curug Cikanteh, Curug Awang), Pantai Palangpang, Tebing Panenjoan, Puncak Darma, bukit, gua, dan situs-situs geologis lainnya yang tersebar di 8 Kecamatan dan 74 Desa.

Geopark Ciletuh menjadi tempat wisata yang memiliki banyak keunggulan dibandingkan dengan tempat wisata lainnya yaitu sebagai sarana pendidikan, tempat penelitian, maupun sebagai tempat wisata. Dengan banyaknya wisatawan yang mengunjungi Geopark Ciletuh, maka fasilitas yang dibutuhkan akan semakin banyak pula, seperti penginapan, restoran, pemandu wisata, hingga toilet umum. Selain itu, buah tangan khas Geopark Ciletuh, seperti Batik Pakidulan maupun berbagai makanan olahan pun akan banyak dicari oleh wisatawan.

Tahun 2020 merupakan tahun yang menguji hampir semua sektor kehidupan, termasuk sektor pariwisata yang menjadi tumpuan hidup banyak orang. Adanya pandemi Corona Virus Disease 2019 (COVID-19) yang menyerang seluruh dunia membuat sektor pariwisata terhenti untuk beberapa waktu. Pada pertengahan Juli kasus positif di Indonesia sudah mencapai lebih dari 80.000 orang dan belum terlihat adanya penurunan yang signifikan. Saat ini pemerintah belum membuka tempat wisata secara utuh untuk dikunjungi oleh wisatawan lokal maupun asing.
Pandemi memaksa pemerintah untuk membuat peraturan agar wisatawan tidak berkunjung ke tempat wisata untuk sementara, termasuk Geopark Ciletuh. Hal tersebut dilakukan untuk menekan penyebaran COVID-19 yang belum dapat dikendalikan sepenuhnya.

COVID-19 merupakan wabah penyakit yang saat ini menyebar di seluruh dunia. Awal ditemukan di Wuhan, China, kini COVID-19 hampir merata menjangkit seluruh negara di dunia dengan kasus positif yang tidak sedikit. World Health Organization (WHO) menyebutkan, COVID-19 merupakan virus yang dapat menyebabkan infeksi pada saluran pernapasan dengan sifat penyebaran yang cukup cepat. Dalam keputusan Presiden No. 12 tahun 2020, Indonesia telah menetapkan COVID-19 sebagai bencana nasional non alam.

WHO menyebutkan penyebaran COVID-19 dapat melalui percikan cairan saat berbicara yang masuk melalui mulut, hidung, dan mata. Percikan cairan tersebut dapat menempel pada benda sehingga kemungkinan orang dapat terinfeksi menjadi tinggi. Atas hal tersebut pemerintah mengeluarkan peraturan untuk membatasi kegiatan masyarakat ketika berada di luar rumah. Dalam masa pandemi COVID-19 beberapa tempat yang memungkinkan untuk orang berkumpul ditutup untuk sementara waktu, termasuk tempat-tempat pariwisata. Dalam protokol percepatan penangangan 
pandemi COVID-19, Gugus Tugas Penanganan COVID-19 mengatakan pandemi COVID-19 memiliki potensi risiko yang cukup besar apabila tidak dilakukan penanganan dengan cepat dan komprehensif. Dalam protokol percepatan penanganan COVID-19 juga disebutkan bahwa koordinasi dan komunikasi merupakan aspek yang sangat penting, mengingat dalam penanganan pandemi COVID-19 melibatkan banyak pihak, mulai dari pemerintah sampai dengan masyarakat umum.

Dengan adanya pandemi COVID-19 sudah dipastikan akan terjadi penurunan jumlah wisatawan yang mengunjungi Geopark Ciletuh di tahun 2020, terutama kunjungan dari wisatawan asing. Dengan penurunan wisatawan tersebut, maka akan berpengaruh pada penurunan ekonomi termasuk di sektor pendukung pariwisata lainnya, seperti transportasi, penginapan dan hotel, restoran, serta semua pelaku usaha yang menggantungkan nasibnya pada sektor pariwisata di Geopark Ciletuh. Pada akhirnya COVID-19 memaksa para pelaku usaha di sektor pariwisata mengurangi jumlah pekerjanya, serta membuat tingkat pendapatan daerah dan perekonomian ikut menurun.

Pandemi COVID-19 menjadi sebuah tantangan bagi sektor pariwisata untuk dapat berjalan ditengah pandemi dengan memberikan rasa aman kepada masyarakat, baik wisatawan maupun masyarakat lokal di sekitar tempat wisata. Disinilah peran pemeritah dibutuhkan untuk membuat kebijakan-kebijakan yang dapat melindungi masyarakat dari pandemi COVID-19. Salah satu kebijakan yang telah dibuat oleh pemerintah yaitu adanya protokol kesehatan yang wajib diikuti oleh seluruh masyarakat, seperti memakai masker, rutin mencuci tangan dengan sabun, memakai handsanitizer, serta menerapkan jaga jarak di tempat keramaian. Adapun kebijakan pemerintah yang ditujukan untuk tempat wisata yaitu adanya tindakan pencegahan yang perlu dilakukan, seperti memperhatikan informasi terkini mengenai COVID-19, melakukan pembersihan dengan desinfektan secara berkala di tempat umum, menyediakan fasiltas untuk mencuci tangan, memaksimalkan sirkulasi udara, menggencarkan propaganda pelindungan diri dari COVID-19, seperti memakai masker, melakukan pemeriksaan suhu pada pengunjung, memastikan para pekerja di sektor pariwisata memahami pelindungan diri dari COVID-19, menyediakan pos kesehatan, menerapkan jaga jarak bagi pengunjung maupun pekerja, mengusahakan penggunaan metode pembayaran non tunai, dan lain sebagainya.

PemahamanmengenaipandemiCOVID-19, protokol kesehatan dan kegiatan pariwisata di masa pandemi COVID-19 perlu diberikan kepada masyarakat luas, khususnya bagi 
masyarakat di sekitar wilayah Geopark Ciletuh. Adanya komunikasi secara persuasif, serta efektif dan efisien diperlukan dalam menekan penyebaran pandemi COVID-19 di Geopark Ciletuh sehingga dibutuhkan stake holder yang menguasai dan paham mengenai bidang tersebut. Public relations (PR) atau hubungan masyarakat (humas) merupakan proses komunikasi yang dilakukan oleh sekelompok orang/organisasi ataupun individu yang bersifat persuasif atau ajakan untuk mencapai suatu tujan tertentu. PR diharapkan menjadi 'jembatan' yang mampu memberikan pehaman kepada masyarakat mengenai sesuatu yang ingin disampaikannya. Sebuah pemerintahan memiliki berbagai bidang didalamnya termasuk humas atau PR yang memiliki peran untuk menciptakan keselarasan, kerjasama, serta menciptakan citra lembaga pemerintahan yang baik di dalam masyarakat (Lamarang, 2013). Dalam ranah kerjanya, PR akan melakukan komunikasi baik itu langsung secara verbal maupun dengan menggunakan media komunikasi yang ada saat ini seperti radio, TV, media sosial, dan lainnya.

Peran pemerintah sebagai pembuat dan penentu kebijakan sangat diperlukan dalam membantu memberikan informasi dan pemahaman kepada masyarakat dengan dibantu oleh PR di dalam pemerintahan. Informasi maupun kebijakan-kebijakan yang dibuat akan diterima dan dipahami oleh masyarakat apabila PR dalam pemerintahan dapat menyampaikannya dengan baik sehingga akan tercipta rasa kepercayaan masyarakat kepada informasi atau kebijakan-kebijakan yang telah dibuat oleh pemerintah.

Terdapat dua fakta dasar yang menjadi landasan pemikiran humas dalam pemerintahan. Pertama, lembaga pemerintahan memiliki tanggung jawab dalam memberikan penjelasan mengenai regulasi yang telah dibuatnya dan masyarakat memiliki hak untuk mengetahui segala informasi dari pemerintah. Kedua, terdapat kebutuhan dari pemerintahan untuk menerima segala macam masukan dari masyarakat dengan tujuan untuk mendapatkan dukungan dari masyarakat (Moore, 2004).

Peran PR pemerintah sangat menentukan suatu informasi dapat diterima dengan baik oleh masyarakat dan timbal balik dari masyarakat pun dapat sampai kepada pemerintah. Dalam perannya, PR dalam pemerintahan harus mengetahui peranannya sebagai komunikator yang baik untuk memberikan informasi kepada individu atau kelompok dan menerima infromasi, serta aspirasi yang selanjutnya akan menjadi acuan pemerintah dalam membuat kebijakan-kebijakan yang sekiranya diperlukan oleh masyarakat.

Melalui humas, pemerintah dapat menjelaskan mengenai kebijakan ataupun tindakan tertentu, serta aktivitas 
kepemerintahannya. Ruslan mengatakan bahwa terdapat beberapa hal yang dilakukan oleh humas dalam melaksanakan tugasnya, yaitu: (1) Mengamati dan mempelajari harapan-harapan dan aspirasi yang ada dalam masyarakat (learning about public desires and aspiriration).

(2) Memberikan informasi maupun saran yang dibutuhkan oleh masyarakat (advising the public about what is desired). (3) Mencipatakan hubungan yang harmonis antara masyarakat dengan pemerintahan (ensuring satifactory contact between public and government official). (4) Memberikan informasi mengenai segala macam aktivitas maupun kebijakan yang telah di lakukan maupun di buat oleh pemerintah (well-informed about what an agency is doing) (Aras, 2014).

Pada masa COVID-19, kebijakan pemerintah dalam melindungi masyarakatnya sangatdiperlukanuntukmengurangikekhwatiran ditengah masyarakat. Seluruh informasi dan kebijakan yang telah dirumuskan akan menjadi tanggung jawab PR untuk disebarluaskan kepada masyarakat. Selain itu, PR juga memiliki tanggung jawab terhadap informasi yang tidak benar dan berkewajiban untuk meluruskan informasi tersebut. PR pemerintah menjadi pihak terdepan dalam menghadapi masyarakat untuk menyampaikan informasi, pesan maupun kebijakan-kebijakan, baik itu melalui media komunikasi maupun disampaikan secara langsung. Di tengah pandemi COVID-19 peran PR pemerintah sangat dibutuhkan, salah satunya dalam pengembangan pariwisata. Kebijakankebijakan yang telah dibuat perlu disampaikan kepada masyarakat sehingga 'roda' sektor pariwisata dapat berputar kembali dan tentunya dengan menerapkan protokol kesehatan yang ketat.

Berdasarkan uraian tersebut di atas, maka identifikasi masalahnya yaitu bagaimana peran government public relations dalam pengembangan pariwisata pada masa pandemi COVID-19 di Geopark Ciletuh, Kabupaten Sukabumi, Provinsi Jawa Barat?. Tujuan dari penelitian ini untuk menjelaskan peran government public relations dalam pengembangan pariwisata pada masa pandemi COVID-19 di Geopark Ciletuh, Kabupaten Sukabumi, Provinsi Jawa Barat.

\section{METODE PENELITIAN}

Penelitian mengenai government public relations dalam pengembangan pariwisata pada masa pandemi COVID-19 di Geopark Ciletuh dilakasanakan dengan metode deskriptif kualitatif dengan pendekatan yang digunakan yaitu studi lapangan dengan wawancara dan observasi. Penelitian deskriptif menggambarkan keadaan sebenarnya yang terjadi pada saat penelitian. Dalam penelitian ini akan tergambarkan dampak pandemi COVID-19 
pada sektor wisata di Geopark Ciletuh dan upaya yang dilakukan oleh humas pemerintahan untuk menanggulangi permasalahan yang terjadi akibat pandemi COVID-19. Data yang disajikan dalam penelitian dengan menggunakan metode diskriptif yaitu uraian mengenai masalah yang benar-benar terjadi di lapangan dalam bentuk deskriptif bukan disajikan dalam bentuk angkaangka.

Menurut Mulyana, dalam arti sederhana penelitian kualitatif adalah penelitian yang menggunakan banyak metode dalam menelaah permasalahan dalam penelitiannya, serta bersifat interpretif. Beliau juga menambahkan apabila secara konvensional penelitian kualitatif cenderung selalu diartikan sebagai keinginan peneliti untuk menelaah suatu makna, konteks, dan suatu pendekatan yang menyeluruh terhadap fenomena (Mulyana, 2008). Senada dengan apa yang dikatakan Salim dan Syahrum bahwa penelitian kualitatif digunakan untuk memahami realitias dan sistem makna budaya sehingga dapat dirumuskan teori-teori baru di dalam kehidupan. Dalam penelitian kualitatif, seorang peneliti dituntut untuk dapat mencari dan menggali data yang diucapkan oleh narasumber atau sumber data obeyek penelitian (Walidin \& Idris, 2015).

Dikutip oleh Chariri, mengatakan terdapat beberapa ciri penelitian kualitatif, diantaranya peneliti dapat berperan dalam membentuk pengetahuan baru, peneliti membentuk hubungan dengan narsumber dan menghasilkan suatu pengetahuan baru yang dapat dipahami oleh pembaca, hasil penelitian dapat tersusun dengan runut dan menjawab pertanyaan pembaca, seorang peneliti harus memliki pemahaman terhadap pendapat dari objek/ subjek penelitian, dan penelitian kualitatif harus dapat menjelaskan secara deskriptif dengan jelas dan terperinci (Chariri, 2009).

Data primer adalah sekumpulan informasi yang diperoleh dari sumber maupun objek penelitian di lapangan, baik dilakukan dengan wawancara, Focus Group Discussion (FGD), maupun dengan observasi. Pada penelitian ini data primer diperoleh dengan melakukan wawancara kepada narasumber dan observasi di Desa Tamanjaya Kecamatan Ciemas yang merupakan salah satu destinasi wisata yang sering dikunjungi oleh wisatawan di Geopark Ciletuh.

Pada penelitian ini wawancara ditujukan untuk mengetahui kejadian dan kebijakan pemerintah, khususnya government public relations dalam mengembangkan pariwisata Geopark Ciletuh dalam masa pandemi COVID-19. Kegiatan wawancara dilakukan oleh pewawancara dan narasumber. Pewawancara merupakan pihak yang memberikan beberapa pertanyaan kepada narasumber dengan tujuan untuk mendapatkan informasi sebanyak- 
banyaknya sehingga tujuan dari kegiatan wawancara pun terpenuhi. Sementara narasumber merupakan pihak yang menjawab pertanyaan yang diajukan oleh pewawancara. Narasumber pada penelitian government public relations dalam pengembangan pariwisata pada masa pandemi COVID-19 di Geopark Ciletuh adalah Bapak Utis yang merupakan Kepala Desa Tamanjaya, Kecamatan Ciemas, Kabupaten Sukabumi, Jawa Barat.

Observasi merupakan kegiatan pengamatan di lapangan penelitian, baik itu lingkungan penelitian, individu maupun kelompok serta peristiwa di lapangan. Dalam Hasanah, mengatakan bahwa observasi merupakan suatu yang fundamental dalam kegiatan pengumpulan data sebuah penelitian kualitatif, khususnya dalam penelitian yang menyangkut kondisi sosial dan tingkah laku manusia (Adler \& Adler, 1987). Hal tersebut di dukung oleh Walidin \& Idris, yang menyebutkan bahwa observasi merupakan studi yang direncanakan dan dilakukan secara sistematis mengenai fenomena sosial dan gejala-gejala psikis melalui pengamatan dan pencatatan. Beliau menambahkan observasi akan membantu dalam mengetahui permasalahan secara luas dan fokus terhadap masalah yang akan diteliti (Walidin \& Idris, 2015), .

Observasi memiliki beberapa tahapan, diantaranya pemilihan (selection), tahapan pemilihan mempengaruihi obyek yang akan diamati, pembahasan yang akan dibuat, serta kesimpulan yang akan diambul. Pengubahan (provocation), observasi bersifat aktif dan mengubah perilaku tanpa mengurangi kewajaran dan kealamiahan dari obyek penelitian. Pencatatan (recording), upaya dalam mendokumentasikan data baik melalui pencatatan, rekaman suara, maupun gamabar yang didapatkan dari lapangan, sehingga tidak ada data yang tertinggal. Pengkodean (encoding), proses dalam menyederhanakan data yang telah didapatkan di lapangan melalui metode reduksi data. Rangakaian perilaku dan suasana (test of behavior setting). In situ, pengamatan yang dilakukan secara alamiah dengan mengamati kejadian dilapangan secara langsung. Serta observasi untuk tujuan empiris yaitu menghasilkan teori dan hipotesis (Hasanah, 2017).

\section{HASIL DAN PEMBAHASAN}

Saat ini pandemi COVID-19 sudah rata menjangkau 34 Provinsi di Indonesia. Pada pertengahan Juli 2020, pasien positif di Indonesia sebanyak lebih dari 86.000 dengan lebih dari 4000 orang meninggal dunia. Sementara di Jawa Barat lebih dari 5000 orang terjangkit virus ini dengan pasien yang meninggal sebanyak lebih dari 190 orang (Beranda Satgas Penanganan COVID-19, n.d.). 
Saat ini seluruh negara berlomba mencari vaksin dari COVID-19 agar dapat terkendali penyebarannya. Berbagai pihak telah membuat model penelitian untuk memprediksikan waktu pandemi COVID-19 akan berakhir. Dalam sebuah artikel, Guru Besar Statistika Universitas Gajah Mada, Prof. Dedi Rosadi bersama rekannya menyebutkan, berdasarkan model hybrid kompartemen SIR-Regresi-RuntunWaktu, COVID-19 diprediksikan akan berakhir pada awal November 2020 dengan kasus positif sebanyak 112 ribu penderita. Sementara dengan menggunakan model Probabilistic Data Driven Model, COVID-19 di Indonesia akan mencapai puncak pandemi pada akhir Juli sampai dengan akhir Agustus 2020, dan berakhir pada Februari 2021, dengan penderita positif sebanyak 227 ribu kasus (Ika, 20 Juli 2020).

Berdasarkan beberapa penelitian yang telah dilakukan, COVID-19 dapat dengan mudah menginfeksi dengan penyebaran droplet dari orang terinfeksi kepada orang yang sehat dengan masuk ke dalam tubuh melalui mulut, hidung, dan mata. Pada umumnya COVID-19 menyerang saluran pernapasan dengan gejala pasien terjangkit yaitu, demam, batuk kering dan rasa lelah (who.int, 2020). Namun saat ini banyak pasien yang terpapar COVID-19 tidak menunjukan gejala sama sekali atau biasa disebut dengan Orang Tanpa Gejala (OTG) sehingga sulit untuk membedakan antara orang sehat dengan OTG selain dengan melakukan swab test. Kementerian Kesehatan RI (2020) dalam Pedoman Pencegahan dan Pengendalian Corona Virus Disease menyebutkan, COVID-19 dapat menyebar melalui kontak erat dan droplet dari penderita COVID-19. Penularan COVID-19 dapat dengan cepat menyebar ditengah masyarakat karena tanpa disadari masyarakat sering menyentuh bendabenda yang telah terkontaminasi COVID-19 di tempat-tempat umum, lalu menyentuh bagian muka mereka sehingga COVID-19 masuk kedalam tubuh dan pada umumnya akan telihat gejala setelah lima hari terinfeksi COVID-19.

Dalam Keputusan Menteri Kesehatan Republik Indonesia Nomor HK. 01.07/ Menkes/413/2020 tentang Pedoman Pencegahan dan Pengendalian Corona Virus Disease 2019 (COVID-19) disebutkan bahwa dengan jumlah kasus kematian yang semakin meningkat dan mengganggu sektor politik, ekonomi, pertahanan dan keamanan, kesejahteraan masyarakat, maka pemerintah dalam Keputusan Pemerintah Nomor 11 Tahun 2020 menetapkan Kedaruratan Kesehatan Masyarakat akibat Corona Virus Disease 2019 (COVID-19). Undang-Undang No. 6 Tahun 2018 menyebutkan bahwa Kedaruratan Kesehatan masyarakat merupakan kejadian luar biasa yang menyerang kesehatan masyarakat, ditandai dengan adanya penyakit menular yang 
disebabkan oleh radiasi nuklir, kontaminasi kimia, pencemaran biologi, bioterorisme, dan pangan yang dapat membahayakan kesehatan hingga beroptensi untuk mnyebar secara luas, baik lintas daerah maupun lintas negara.

Berdasarkan hal tersebut maka pemeritah membuat kebijakan Pembatasan Sosial Berskala Besar (PSBB) dalam menekan penyebaran COVID-19 karena telah mengganggu kestabilan segala sektor, mulai dari sektor kesehatan sampai dengan sektor keamanan negara, termasuk dalam sektor pariwisata. Di dalam Undang-Undang No.6 tahun 2018 disebutkan pula bahwa PSBB yaitu pembatasan kegiatan tertentu penduduk dalam suatu wilayah yang diduga terinfeksi penyakit dan/atau terkontaminasi sedemikian rupa untuk mencegah kemungkinan penyebaran penyakit atau kontaminasi. PSBB merupakan kebijakan pemerintah dalam melindungi kesehatan masyarakatnya. Meskipun begitu, tidak menutup kemungkinan bahwa PSBB akan mempengaruhi sektor perekonomian suatu daerah, terutama dalam sektor pariwisata.
Kabupaten Sukabumi menjadi salah satu daerah di Jawa Barat yang menjadi destinasi favorit untuk berwisata. Dengan luas wilayah sekitar 419.470 ha, Kabupaten Sukabumi menjadi wilayah terluas di Jawa Barat dengan berbagai destinasi wisata yang dapat dikunjungi. Terdapat berbagai macam objek wisata yang menarik untuk dikunjungi seperti objek wisata alam, diantaranya hutan, pantai, muara, air panas, situ, air terjun, goa, geopark, objek wisata buatan, seperti tempat rekreasi, peninggalan sejarah, perkebunan teh/bunga, objek wisata minat khusus, seperti arung jeram, arung gelombang, diving, surfing, wisata religi, wisata buru (Dinas Pariwisata Kabupaten Sukabumi, 2019). Banyaknya destinasi pariwisata pilihan di Kabupaten Sukabumi sehingga Kabupaten Sukabumi menjadi salah satu daerah tujuan wisata, terutama bagi masyarakat Provinsi Jawa Barat, Provinsi Jakarta, Provinsi Banten, dan sekitarnya. Berikut jumlah wisatawan yang memasuki Kabupaten Sukabumi sampai dengan tahun 2018 .

Tabel 1 Jumlah Wisatawan Dalam Negeri dan Luar Negeri ke Kabupaten Sukabumi Tahun 2016-2018

\begin{tabular}{cccc}
\hline \multirow{2}{*}{ Tahun } & Wisatawan & Wisatawan & \\
& & & Jumlah \\
& Dalam Negeri & Luar Negeri & \\
\hline 2016 & 3.485 .066 & 115.547 & 3.600 .613 \\
2017 & 3.657 .767 & 122.810 & 3.780 .577 \\
2018 & 3.719 .483 & 127.145 & 3.846 .628 \\
\hline
\end{tabular}

Sumber: Dinas Pariwisata Kabupaten Sukabumi, 2019 
Menurut Kepala Dinas Pariwisata Kabupaten Sukabumi, Usman Jaelani, pada pertengahan tahun 2019 jumlah wisatawan yang mengunjungi Kabupaten Sukabumi yaitu sebanyak 2,5 juta orang dan telah mencapai target, tidak menutup kemungkinan akan terus melonjak sampai akhir tahun 2019 (Republika. co.id, 18 Juni 2019). Dari data di atas terlihat peningkatan wisatawan setiap tahunnya, mulai dari wisatawan dalam negeri maupun wisatawan yang berasal dari luar negeri. Tentu hal ini sangat berpengaruh terhadap roda perekonomian di daerah Kabupaten Sukabumi. Dalam hal ini diperkirakan terdapat beberapa faktor yang mempengaruhi tingkat kunjungan wisatawan ke Kabupaten Sukabumi, diantaranya daya tarik wisata yang dimilki oleh Kabupaten Sukabumi, fasilitas penunjang wisata, seperti penginapan, tempat makan, dan fasilitas penunjang lainnya, serta keamanan di tempat wisata.

Salah satu destinasi wisata yang menjadi daya tarik wisatawan untuk mengunjungi Kabupaten Sukabumi adalah Geopark Ciletuh. Dengan luas wilayah sekitar 128.000 ha yang tersebar di 8 Kecamatan dan 74 Desa, Geopark Ciletuh memiliki berbagai destinasi wisata alam yang terbentuk secara alami dan menarik untuk dikunjungi. Berdasarkan Peraturan Pemerintah No. 50 Tahun 2011, Geopark Ciletuh termasuk kedalam Kawasan Strategi Pariwisata Nasional karena memiliki fungsi utama pariwisata dan potensi pengembangan wisata. Didalamnya, Geopark Ciletuh memiliki aspek pendukung, diantaranya beragamnya sumber daya wisata yang menjadi daya tarik wisata, potensi pertumbuhan ekonomi dan sosial-budaya, serta pemberdayaan lingkungan. Geopark Ciletuh, Kabupaten Sukabumi, Provinsi Jawa Barat termasuk ke dalam Rencana Induk Pembangunan Kepariwisataan Nasional karena memiliki tujuan untuk meningkatkan mutu pariwisata, baik kualitas maupun kuantitas destinasi wisata dengan cara publikasi di berbagai media komunikasi, baik cetak, elektronik, maupun online, mampu menggerakan roda pereknomian daerah dan negara, serta mampu mengembangkan lembaga, manajemen, dan tata kelola pariwisata secara profesional, efektif dan efisien.

Kawasan Geopark Ciletuh memang menjadi daya tarik wisata di Kabupaten Sukabumi karena menyuguhkan kekayaan alam yang indah sehingga wisatawan yang datang pun terus meningkat, baik wisatawan dalam negeri maupun wisatawan luar negeri. Daya tarik Geopark Ciletuh pun tidak sebatas pada pesona alam yang beragam, namun terdapat pula pada budaya sertempat, serta adanya kampung adat yang menjadi daya tarik sendiri untuk menjelajahi Geopark Ciletuh. Seperti data di bawah ini yang menyajikan jumlah wisatawan pada tahun 2015 - Juni 2018. 
Tabel 2 Jumlah Wisatawan yang Mengunjungi Geopark Ciletuh Periode 2015 - Juni 2018

\begin{tabular}{cc}
\hline Tahun & Jumlah Wisatawan \\
\hline 2015 & 561.122 \\
2016 & 719.726 \\
2017 & 967.312 \\
Juni 2018 & 289.517 \\
\hline
\end{tabular}

Sumber: Pusat Informasi Geopark Ciletuh -

Pelabuhanratu, dalam Nainggolan, 2018

Dari tabel 2 terlihat jumlah wisatawan yang datang ke Geopark Ciletuh mengalami peningkatan setiap tahunnya. Apabila dilihat dari data wisatawan yang mengunjungi Kabupaten Sukabumi secara keseluruhan, diperkirakan ada peningkatan pula di tempat wisata Geopark Ciletuh pada tahun 2019. Adanya peningkatan wisatawan yang datang ke Kabupaten Sukabumi, khususnya Geopark Ciletuh tidak terlepas dari kegiatan promosi, baik melalui media masa maupun media sosial yang dilakukan oleh pemerintah daerah setempat. Tercatat hingga triwulan kedua 2019 hingga Juni, jumlah wisatawan nasional maupun internasional yang datang ke Geopark Ciletuh mencapai 2,5 juta orang (Republika. co.id, 18 Juni 2019). Dalam penelitian yang telah dilakukan oleh Santoso \& Winarni (2018) menunjukan strategi pemerintah Kabupaten Sukabumi dalam pengembangan Geopark Ciletuh yaitu dengan menetapkan kebijakankebijakan dasar, mempersiapkan sumber daya dalam mendorong kegiatan Geopark Ciletuh, dan merealisasikan kebijakan-kebijakan yang telah dibuat. Selain itu, disebutkan pula dalam Undang-Undang Republik Indonesia No. 10 Tahun 2009 Tentang Kepariwisataan menyebutkan Pembangunan kepariwisataan dilakukan berdasarkan asas manfaat kekeluargaan, adil dan merata, keseimbangan, kemandirian, kelestarian, partisipatif, berkelanjutan, demokratis, kesetaraan, dan kesatuan. Hal tersebut diwujudkan melalui pembangunan pariwisata dengan memprioritaskan keberagaman, kenunikan, dan ciri khas budaya dan alam, serta kebutuhan masyarakat untuk melakukan kegiatan wisata.

Namun peningkatan wisatawan yang terjadi hingga tahun 2019 akan dipastikan menurun akibat adanya pandemi COVID-19. Penurunan jumlah wisatawan yang mengunjungi Geopark Ciletuh diakibatkan belum terlihat kondisi yang kondusif apabila mengunjungi tempat wisata, termasuk untuk datang dan menjelajahi Geopark Ciletuh. Belum ditemukannya vaksin yang dapat menghambat perkembangan COVID-19 menjadi salah satu alasan bagi wisatawan untuk mengunjungi tempat wisata, terutama bagi warga negara asing yang ingin berkunjung ke Geopark Ciletuh. Penurunan jumlah wisatwan tersebut maka akan berpengaruh ke sektor ekonomi sehingga peningkatan ekonomi masyarakat di 
sekitar Geopark Ciletuh menjadi terhambat.

Pada sektor pariwisata, pandemi COVID-19 menghentikan segala macam aktivitas pariwisata yang mengakibatkan penurunan tingkat ekonomi masyarakat, khususnya yang berada di sekitar daerah wisata tersebut. Menurut Herdiana (2020) terdapat lima aspek di sektor wisata yang terdampak oleh pandemi COVID-19, yaitu sektor ekonomi, dikarenakan berhentinya kegiatan di sektor pariwisata sehingga berpengaruh pada jasa pariwisata, seperti transportasi, penginapan, pemandu wisata, dan lain sebagainya yang tidak mendapatkan pemasukan dana untuk memutar roda usahanya. Kedua, sektor pajak, dikarenakan tidak adanya aktifitas wisata maka akan terjadi penurunan dari target penerimaan pajak sektor pariwisata. Ketiga, sektor tenaga kerja. Pandemi memaksa pemilik usaha untuk menghentikan usahanya karena tidak adanya pendapatan yang diterima sehingga membuat mereka merumahkan para pegawainya karena tidak sanggup untuk memberikan gaji/upah. Keempat, aspek promosi pariwisata. Pandemi menghentikan kegiatan promosi tempat wisata yang pada akhirnya menurunkan pamor dari tempat wisata karena pemasaran wisata pun tidak berjalan dengan semestinya. Kelima, aspek keberlanjutan usaha pariwisata. Masa pandemi COVID-19 ini belum diketahui kapan akan berakhir, sehingga belum ada kepastian dalam keberlanjutan tempat wisata, apakah akan bertahan atau tidak.

Untuk menanggulangi penyebaran penyakit akibat COVID-19, pemerintah telah membuat kebijakan Pembatasan Sosial Berskala Besar (PSBB) dengan salah satu kebijakannya yaitu menutup fasilitas umum, seperti taman, sarana olahraga, dan destinasi wisata sampai dengan waktu yang belum dapat ditentukan. Tujuan pemerintah mengeluarkan kebijakan PSBB tersebut untuk menekan penyebaran pandemi COVID-19, akan tetapi tetap memperhatikan sektor ekonomi untuk dapat tetap berjalan. Di Kabupaten Sukabumi, jumlah kasus positif terdapat 57 kasus yang di hitung per tanggal 6 Maret 2020 sampai dengan 20 Juli 2020 (pikobar. jabarprov.go.id). Apabila diambil rata-rata per 7 hari maka banyaknya kasus terkonfirmasi positif yaitu kurang dari satu orang. Meskipun kasus positif di Kabupaten Sukabumi dan kebijakan PSBB yang diberlakukan sejak April telah dilonggarkan, namun pemerintah Kabupaten Sukabumi tidak serta merta untuk membuka tempat wisata Geopark Ciletuh.

Bapak Utis (Kuwu Desa Tamanjaya)
"pembatasan sosial secara ketat telah
dilakukan oleh pemerintahan Desa
Tamanjaya yaitu dengan menutup jalan
yang mengarah ke wisata Amphitheater
Geopark Ciletuh di Desa Tamanjaya. Hal
tersebut dilakukan karena dikhawatirkan
wisatawan akan tetap mengunjungi
Amphitheater di saat PSBB sedang
dilaksanakan dan memicu kluster baru
penyebaran COVID-19 di area Geopark


Ciletuh. Dengan ketatnya peraturan protokol kesehatan, maka Desa Tamanjaya masih bestatus zona hijau atau belum ada warga di Desa Tamanjaya yang terindikasi sakit karena COVID-19. PSBB merupakan salah satu tindakan yang cukup efektif dalam mengurangi tingkat penularan COVID-19".

Kurniawan (9 September 2020) juga mengatakan, dengan mengutip Windhu Purnomo, ahli Epidemologi dari Universitas Airlangga, pembatasan pergerakan manusia merupakan satu-satunya cara mencegah penyebaran penyakit akibat COVID-19. Peningkatan jumlah posistif COVID-19 karena masyarakat tidak disiplin dalam melaksanakan protokol kesehatan, seperti masih berkumpul lebih dari dua orang, tidak memakai masker, jarang mencuci tangan dan tidak menjaga jarak saat berada di kerumunan.

Diperkirakan protokol kesehatan di tempat wisata akan menjadi salah satu aspek utama yang akan lebih diperhatikan oleh wisatawan dan akan menjadi salah satu program dalam pengembangan pariwisata dalam masa pandemi COVID-19. Menurut Hakim, wisatawan akan semakin waspada dalam merencanakan kegiatan wisata. Apabila di tempat wisata tersebut memiliki tingkat ancaman tertular tinggi, maka akan menurunkan minat wisatawan untuk berkunjung ke tempat wisata tersebut. Tujuan dari seseorang melakukan perjalanan wisata adalah untuk menadapatkan pengalaman baru, akan tetapi pada masa pandemi COVID-19 ini seseorang akan berpikir terlibih dahulu dalam melakukan perjalanan wisata karena pandemi COVID-19 akan menjadi ancaman dalam melakukan perjalanan wisata. Hakim menambahkan, terdapat tiga faktor utama yang menjadi indikator wisatawan akan melakukan wisata atau tidak, diantaranya kondisi kehidupan di tempat wisata, tingkat higienitas, dan ketersediaan perwatan medis di tempat wisata (Hakim, 2020).

Geopark Ciletuh menjadi salah satu ikon di Kabupaten Sukabumi dan menjadi bagian dari kekayaan alam di Jawa Barat. Dalam masa pandemi COVID-19 diperlukan penyampaian informasi yang baik agar Geopark Ciletuh dapat beradaptasi dengan keadaan saat pandemi COVID-19 ini. Peran PR pemerintahan diperlukan dalam menyampaikan informasi untuk memulihkan kondisi pariwisata Geopark Ciletuh dan sebagai pengembangan pariwisata Geopark Ciletuh paska pandemi COVID-19. PR pemerintahan juga memiliki tanggung jawab dalam membangun citra dan reputasi dari lembaga pemerintahannya sehingga hubungan kepercayaan dari masyarakat kepada lembaga pemerintah akan terbangun. Selain itu, seorang PR pemerintahan harus memiliki strategi dan kemampuan komunikasi yang baik dan benar dalam memberikan suatu informasi, baik dengan menggunakan media komunikasi 
maupun tidak, sehingga informasi tersebut dapat ditafsirkan dengan baik dan dipahami oleh penerima informasi.

Menurut Nugroho \& Sulistyorini dalam Komunikasi Bencana, tugas dan tanggung jawab PR pemerintahan untuk memberikan penerangan, informasi, dan edukasi tentang pelayanan masyarakat (public service), mampu meyakinkan masyarakat untuk berpartisipasi melaksanakan program pembangunan dengan semangat kejujuran dan keterbukaan memberikan pelayanan, serta pengabdian (Nugroho \& Sulistyorini, 2018). Kunci dari tugas Humas pemerintah adalah sebagai komunikator untuk membantu terlaksananya program pembangunan. Mereka juga harus memiliki hubungan yang positif dengan berbagai kalangan dan memiliki konsep kerja terencana yang semuanya bermuara pada upaya untuk membentuk citra positif bagi lembanganya. Humas pemerintah dalam bertugas memiliki peran ganda yakni bertindak sebagai komunikator bagi penyebaran informasi program pembangunan, sekaligus juga harus mampu menyerap aspirasi masyarakat, serta menyelaraskan dengan kepentingan lembaganya untuk mencapai tujuan bersama.

Dalam pengembangan pariwisata, PR pemerintahan tidak akan lepas dari strategi komunikasi, terutama pada masa pandemi COVID-19 seperti ini. Pemerintah perlu ekstra bekerja keras agar tempat wisata dapat terus eksis dan menarik perhatian wisatawan, setidaknya mengetahui bahwa tempat wisata tersebut telah siap menghadapi era new normal di masa pandemi COVID-19. Salah satu strategi komunikasi yang dapat dilakukan oleh PR pemerintahan yaitu dengan memanfaatkan media komunikasi digital untuk dapat menginfomasikan tempat wisatanya kepada publik. Pemilihan media komunikasi menjadi salah satu faktor keberhasilan dari strategi komunikasi (Sugiarti, et al., 2007). Rodiah \& Yusup dalam jurnalnya menyimpulkan bahwa dalam strategi komunikasi diperlukan komunikator yang tepat dan dapat memahami informasi yang akan disampaikan kepada penerima informasi, merencanakan pengemasan pesan yang akan disampaikan, mempersiapkan media komunikasi yang akan digunakan, serta mengetahui dan memahami informasi yang ingin diterima oleh penerima informasi (Rodiah \& Yusup, 2018). Strategi komunikasi diperlukan pengetahuan mengenai informasi yang ingin diterima oleh penerima pesan, penyusunan pesan sehingga dapat diterima dan dipahami oleh penerima pesan, metode penyampaian informasi, dan pemilihan media yang akan digunakan untuk penyampaian informasi (Sugiarti, et al., 2007).

Strategi komunikasi yang dilakukan oleh PR pemerintahan dalam memberikan informasi 
mengenai pencegahan COVID-19 di Geopark Ciletuh salah satunya yaitu dengan memasang baliho, poster, maupun spanduk yang berisi ajakan untuk melaksanakan protokol kesehatan bagi masyarakat Geopark Ciletuh maupun masyarakat luar wilayah Geopark Ciletuh. Hal ini dilakukan oleh PR pemerintahan dalam membatasi penyebaran pandemi COVID-19 serta sebagai upaya dalam adaptasi era new normal di tempat wisata. Dengan adanya upaya tersebut, masyarakat dan pengunjung yang datang ke Geopark Ciletuh akan selalu diingatkan untuk berdisiplin dalam menjalankan protokol kesehatan demi kebaikan bersama.

Upaya pengembangan pariwisata di masa pandemi COVID-19, PR pemerintah memegang peran penting untuk memberikan informasi kepada masyarakat mengenai kebijakan yang telah dibuat oleh pemerintah dengan bahasa yang sederhana sehingga mudah dipahami oleh masyarakat luas. PR pemerintah perlu memberikan pemahaman mengapa suatu kebijakan perlu dilaksanakan, tujuan kebijakan itu dibuat, serta manfaat dari kebijakan yang telah dibuat untuk masyarakat. Disamping itu, saat ini media komunikasi telah banyak jenisnya, mulai dari televisi, radio, media cetak, sampai dengan media sosial yang telah dipergunakan oleh masyarakat di berbagai lapisan sehingga informasi ataupun kebijakan mengenai pencegahan COVID-19 pun dapat diterima dengan cepat oleh masyarakat.

Pada pengembangan pariwisata di tengah pandemi COVID-19, pemerintah melalui Kementerian Pariwisata Ekonomi Kreatif mengatakan pemerintah telah menyiapkan program Cleanliness, Health and Safety sebagai adaptasi wisata di era new normal dengan mengikutsertakan para pelaku di bidang wisata dan ekonomi kreatif sehingga sektor pariwista akan produktif kembali di masa yang akan datang (Nisa, 8 Juni 2020). Program Cleanliness, Health and Safety merupakan kebijakan pemerintah yang diharapkan dapat menjadi kebijakan pengembangan pariwisata pada masa pandemi COVID-19, khususnya di Geopark Ciletuh, sehingga sektor pariwisata dapat berjalan kembali dan memutar kembali roda perekonomian di sekitar tempat wisata Geopark Ciletuh. Pengembangan wisata di era new normal menjadi pekerjaan rumah, bukan hanya di Indonesia akan tetapi di seluruh negara di dunia.

Dalam pengembangan pariwisata terdapat delapan poin yang perlu diperhatikan, diantaranya 1. Diperlukan adanya regulasi dalam peningkatan kualitas pariwisata dan kelestarian lingkungan destinasi wisata; 2. Keterlibatan masyarakat sekitar destinasi wisata perlu dilibatkan dalam pengembangan potensi wisata; 3. Publikasi dan promosi destinasi wisata perlu dilakukan secara berkelanjutan; 
4. erlu ditentukan daya tarik wisata yang memiliki ciri khas tersendiri terutama yang bersifat budaya dan alam; 5. Pemerintah pusat perlu berkolaborasi dengan pemerintah daerah atau industri pariwisata dengan sistem yang terbuka, jujur, dan adil dalam mengembangkan pariwisata; 6. Pemerataan jumlah wisatawan perlu dilakukan kepada destinasi wisata di seluruh wilayah Indonesia; 7. Memberikan pemahaman kepada masyarakat sekitar destinasi wisata mengenai fungsi dan peran pariwisata, serta peluang-peluang yang diberikan oleh kegiatan wisata; 8. Diperlukan sarana dan fasilitas yang dapat menunjang kegiatan wisata (Soebagyo, 2018).

Pandemi COVID-19 memang menghambat semua kegiatan di daerah tempat wisata, termasuk di Geopark Ciletuh, akan tetapi pengembangan pariwisata di Geopark Ciletuh tidak harus terhenti. Mempersiapkan sarana protokol kesehatan dalam menekan penyebaran COVID-19 di Geopark Ciletuh sangat diperlukan. Selain itu, peraturan wisata di era new normal perlu diperketat, seperti wisatawan tidak boleh berwisata lebih dari 4 orang dan tetap memperhatikan protokol kesehatannya dengan menerapkan 3M (memakai masker dengan benar, mencuci tangan secara rutin, dan menjaga jarak saat berada di kerumunan).

Kusumawanti, disampaikan oleh Tukul Armadi, Staf Ahli Bidang Sosio-Antropologi
Kementerian Koordinator Bidang Kemaritiman dan Investasi, bahwa Geopark Ciletuh telah mempersiapkan pengelolaan wisata di era new normal atau paska pandemi COVID-19, diantaranya membuat pemetaan hubungan sosial di tengah masyarakat serta hubungan antara makhluk hidup dan lingkungan di sekitar Geopark Ciletuh, mengidentifikasi berbagai macam dampak yang ditimbulkan oleh pandemi COVID-19 di masa pandemi maupun paska pandemi COVID-19, serta mengumpulkan berbagai macam pedoman dan tata kelola sebagai acuan pengelolaan Geopark era new normal. Dalam artikel tersebut beliau menambahkan, perlu dibuat strategi pengelolaan untuk menghasilkan keuntungan dalam sektor ekonomi, budaya dan ekonomi, serta perlu ada pedoman tata kelola yang mungkin akan diperlukan untuk kebijakan, bantuan, kerjasama, dan fasilitas penunjang wisata.

Seorang praktisi PR, khususnya PR pemerintahan harus memiliki kepekaan untuk melihat perubahan-perubahan yang terjadi di dalam masyarakat. Saat pandemi COVID-19, peranan PR pemerintahan sangat di butuhkan dalam menyampaikan informasi yang membuat masyarakat untuk selalu waspada dan memberikan keyakinan, serta energi positif dalam menghadapi bencana Nasional ini. Seperti yang dikatakan oleh Sani (2014), seorang profesional humas atau PR harus 
memiliki kemampuan membaca tren dalam masyarakat, serta dapat menyelaraskan antara informasi kehumasan dengan dinamika sosial di dalam masyarakat. Peningkatan wisatawan di Geopark Ciletuh pada masa pandemi akan berbanding lurus dengan persiapan pemerintah daerah ataupun pengelola pariwisata Geopark Ciletuh dalam pengembangan pariwisata di era new normal.

\section{SIMPULAN}

Pariwisata merupakan salah satu roda utama penggerak ekonomi negara. Saat ini sektor pariwisata merupakan salah satu sektor yang terdampak paling besar oleh pandemi COVID-19. Banyak aspek-aspek di dalam sektor pariwisata yang menjadi korban pandemi COVID-19 ini. Pandemi COVID-19 membuat ketidakstabilan pada aspek ekonomi sehingga memunculkan masalah lain pada sektor pariwisata, diantaranya pemutusan hak kerja oleh pelaku usaha di bidang pariwisata kepada karyawannya, penutupan sejumlah fasilitas penunjang wisata seperti penginapan, hotel, restoran, dan lainnya, serta penurunan jumlah pendapatan daerah. Meskipun begitu, perlu dipersiapkan kebijakan mengenai aturan-aturan dalam menghadapi era new normal dalam masa pandemi maupun setelah pandemi.

Geopark Ciletuh merupakan cagar alam yang harus dijaga, dilestarikan, serta dikembangkan keberadaannya. Dalam massa pandemi COVID-19, Geopark Ciletuh dapat membuat dan beradaptasi dengan kebijakan yang telah dibuat dalam menghadapi pandemi COVID-19. Pengembangan pariwisata lokal dalam masa pandemi diperlukan agar sektor pariwisata tetap berjalan dan ekonomi dapat terbangun kembali. Pengembangan pariwisata lokal dengan protokol kesehatan akan menjadi kewajiban bagi pemerintah dan pengelola wisata. Protokol kesehatan yang telah di buat oleh pemerintah dalam masa pandemi maupun setelahnya merupakan suatu kewajiban yang harus diikuti oleh pengelola, wisatawan maupun masyarakat di sektir tempat wisata.

PR pemerintahan memiliki kewajiban dalam menginformasikan seluruh informasi mengenai pandemi COVID-19 dan kebijakankebijakan pemerintah kepada masyarakat. Dalam pengembangan pariwisata di Geopark Ciletuh pemerintah telah memiliki kebijakan untuk memetakan hubungan sosio-ekologi di kawasan Geopark Ciletuh, mengidentifikasi dampak COVID-19 yang akan terjadi selama pandemi dan paska pandemi, serta melakukan inventarisasi pedoman dan tata kelola Geopark Ciletuh di masa new normal. PR pemerintah memiliki tugas untuk menjembatani antara masyarakat dengan lembaga pemerintahan, dapat menampung aspirasi dari masyarakat dan menyampaikannya kepada lembaga atau 
pemerintah terkait, memberikan informasi yang baik dan dapat dipahami oleh masyarakat.

Peran PR pemerintahan dalam pengembangan pariwisata Geopark Ciletuh dalam masa pandemi COVID-19 diperlukan agar wisatawan tetap mengetahui informasi terbaru dan kesiapan, serta keamanan dari Geopark Ciletuh. Saat ini, informasi mengenai keadaan tempat wisata, kebersihan, dan adanya fasilitas kesehatan di tempat wisata akan menjadi pertimbangan untuk wisatawan dalam melakukan perjalanan wisata. Saat pandemi seperti ini, wisatawan sebagai penerima informasi selalu mencari informasi keamanan dari daerah tempat wisata, sehingga mereka mendapatkan keyakinan untuk pergi berwisata ke tempat tersebut di waktu yang lain. Kebijakan-kebijakan pemerintah pusat maupun daerah menjadi salah satu poin utama dalam pengembangan pariwisata di Geopark Ciletuh dalam masa pandemi COVID-19 saat ini.

\section{DAFTAR PUSTAKA}

Aras, M. (2014). Kegiatan government public relation dalam membangun komunikasi dengan dunia pers: Studi kasus Humas Pemerintah Kota Administrasi Jakarta Timur. Humaniora, 5(2), 1056-1065. https://doi.org/10.21512/humaniora. v5i2.3221

Beranda | Satgas Penanganan COVID-19. (n.d.). Retrieved January 14, 2021, from https://covid19.go.id/
Chariri, A. (2009). Landasan filsafat dan metode penelitian kualitatif. in workshop metodologi penelitian kuantitatif dan kualitatif. Fakultas Ekonomi Universitas Diponegoro.

Dinas Pariwisata Kabupaten Sukabumi. (2019). Laporan Kinerja (Vol. 53, Issue 9).

Hasanah, H. (2017). Teknik-teknik observasi (Sebuah alternatif metode pengumpulan data kualitatif ilmu-ilmu sosial). AtTaqaddum, $\quad 8(1), \quad 21 . \quad$ https://doi. org/10.21580/at.v8i1.1163

Herdiana, D. (2020). Rekomendasi kebijakan pemulihan pariwisata pasca wabah Corona Virus Disease 2019 (COVID-19) di Kota Bandung. Jurnal Master Pariwisata (JUMPA), 7(1), 1-30. https://doi. org/10.24843/JUMPA.2020.v07.i01.p01

Kurniawan, I. (2020). Penerapan kembali psbb, epidemiolog: satu-satunya obat cegah penularan, batasi pergerakan manusia. Prfmnews.Pikiran-Rakyat.Com.

Kusumawanti, R. (2020). Tiga strategi mengelola geopark Ciletuh. Https://Www. Portonews.Com/.

Lamarang, A. (2013). Peranan humas dalam mempromosikan pariwisata di Kabupaten Bolaang Mongondow Utara. ACTA DIURNA KOMUNIKASI, 2(3), 1-12. https://ejournal.unsrat.ac.id/index.php/ actadiurnakomunikasi/article/view/2092

Moore, H. F. (2004). Humas: membangun citra dengan komunikasi. Bandung: Remaja Rosdakarya.

Mulyana, D. (2008). Metode penelitian kualitatif: paradigma baru ilmu komunikasi dan ilmu sosial lainnya. Bandung: Remaja Rosdakarya.

Nisa, C. (2020). Strategi industri pariwisata dalam menghadapi new normal. Https:// Kumparan.Com/. 
Nugroho, S. P., \& Sulistyorini, D. (2019). Komunikasi bencana: membedah relasi bnpb dengan media. pusat data, informasi dan hubungan masyarakat, Badan Nasional Penanggulangan Bencana.

Nur Hakim, I. (2020). Wabah dan peringatan perjalanan dalam persepsi wisatawan. Jurnal Master Pariwisata (JUMPA), 7(1), 31. https://doi.org/10.24843/JUMPA.2020. v07.i01.p02

Pedoman Kesiapsiagaan Menghadapi Coronavirus Disease (COVID-19) Revisi ke-3 (pp. 0-115). (2020). Kementerian Kesehatan Republik Indonesia.

republika.co.id. (2019). Semester 1 2019, 2,5 juta wisatawan kunjungi Sukabumi. Www. Republika.Co.Id.

Rodiah, S., \& Yusup, P. M. (2018). Strategi komunikasi dalam pengembangan desa agro wisata di Kabupaten Pangandaran. Jurnal Signal, 6(2), 1-13. https://doi. org/10.33603/signal.v6i2.1321

Salim, S. (2012). Metodologi Penelitian Kualitatif. Bandung: Cipta Pustaka Media.

Sani, A. (2014). Optimalisasi fungsi humas pemerintah: The optimization of government public relations function. Edutech, 1(1), 78-106. http://jurnal.upi. edu/2872/view/2872/optimalisasi-fungsihumas-pemerintahthe-optimization-ofgovernment-public-relations-function.html Santoso, M. R., \& Winarni, F. (2018). Strategi pemerintah Kabupaten Sukabumi dalam pengembangan ekowisata Geopark Ciletuh. Adinegara, 7(5), 591-602. http:// journal.student.uny.ac.id/ojs/ojs/index. php/adinegara/article/view/12711

Soebagyo. (2018). Strategi pengembangan pariwisata di Indonesia. Liquidity, 1(2), 153-158. https://doi.org/10.32546/ lq.v1i2.145

Sugiarti, T., Amin, H., \& Rezkyawati, S. U. (2016). Strategi komunikasi dinas kebudayaan dan pariwisata dalam pemetaan potensi wisata Kabupaten Buton Tengah. Jurnal Ilmu Komunikasi UHO: Jurnal Penelitian Kajian Ilmu Komunikasi \& Informasi, 1(2), 1-15. http://ojs.uho. ac.id/index.php/KOMUNIKASI/article/ view/1438

UNESCO. (2014). Global geopark network, guidelines and criteria for national geoparks seeking UNESCO's assistance to join the Global Geoparks Network (GGN) (Issue January, p. 13).

Utomo, A. P. (2019). Indonesia jadi nomor 1 tujuan wisata dunia 2019 versi CNTRaveler. Internasional.Kompas.Com.

Walidin, W., \& Idris, S. (2015). Metodologi penelitian kualitatif \& grounded theory. Banda Aceh: FTK Ar-Raniry Press.

who.int. (2020). Pertanyaan dan jawaban terkait coronavirus. Who.Int. 